\title{
Analysis of Marketing Strategies Adopted by Gold Jewelers in Chennai
}

\author{
M. Anbarasi, S. Praveen Kumar
}

\begin{abstract}
The improvement and patterns in the advertising field summon interest and imagination. Socially, the Indian individuals have an extraordinary adoration and interest for gold. Gold isn't an item, however a product. It is homogeneous and undefined. India is esteemed to be the center point of the worldwide gems showcase on account of its low expenses and accessibility of high-talented work. Three tremendous markets for gold gems are China, India, and the US, each agreement it for a one of a kind social hugeness. Securing gems is associated with festivities, connections, self-articulation and trusts later on in these nations. The Research paper draws out a diagram of advertising procedures in the Gold adornments showcase, by taking Thrissur, the Gold Hub of Kerala as a contextual investigation. From the examination it was discovered that promoting methodologies assumes a critical job in gold adornments advertise. Imaginative promoting systems exceptionally impact client purchasing conduct. The investigation empowers the adornments shipper to gadget arrangements, plans and methodologies in an increasingly powerful way to thrive their business.
\end{abstract}

Keywords: Advertisement, Behaviour, Gold, Marketing, Strategies

\section{INTRODUCTION}

The main purpose of choosing this research for analyse and understand the different types of marketing strategies adopted by jewellery shops in chennai[1],[3],[5].

\section{A. Scope of the Study}

The research is done in marketing area to find out the marketing strategies adopted by gold jewellerys in chennai this research helps in finding the strength and weakness of jewellery shops in chennai[2],[4],[6]. Customer's expectation and retailer's opinion have also being observed through this study.

\section{B. Limitations of the Study}

- The information is procured from chennai and such as data collected holds to the respondents of chennai alone.

- The Sample size is limited to 75 .

- While recording the opinions, some respondents could not respond properly.

Revised Manuscript Received on July 22, 2019.

M. Anbarasi, Department of MBA, Bharath Institute of Higher Education and Research, Chennai, India.

Email: praveenkumar.mba@bharathuniv.ac.in

Dr. S. Praveen Kumar, Department of MBA, Bharath Institute of Higher Education and Research, Chennai, India.

Email: praveenkumar.mba@bharathuniv.ac.in
- Some respondents fear to give true information.

\section{Objectives of the Study}

- To identify and understand the product strategies adopted by gold jewelers in chennai.

- To determine and find out the pricing strategies adopted by gold jewelers in chennai.

- To analyse the promotional strategies adopted by gold jewelers in chennai[7],[9],[11].

- To identify the distribution strategies adopted by gold jewelers in chennai.

- To determine and analyse the strength and weakness of gold jewelers in chennai.

\section{RESEARCH DESIGN}

\section{A. Variable Of the Study}

In this research, the variable of the study is Gold jewellery shops in chennai. The population size of this research is 400 jewellery shops in chennai. The researcher get the population through the below website address;

www.yellowpages.sulekha.com

The researcher used Simple Random Sampling method for selecting the sample size from the population. The sample size of the research is 75 jewellery shops in chennai. The researcher used random number method for picking out the 75 jewellery shops from out of 400 jewellery shops[8],[10],[12].

\section{B.Areas Covered In This Study}

Table -1

\begin{tabular}{|l|l|}
\hline NAME OF THE AREA & NO OF SAMPLES \\
\hline T.NAGAR & 20 \\
\hline GREAMS ROAD & 02 \\
\hline TAMBARAM & 05 \\
\hline PARRYS & 05 \\
\hline ANNANAGAR & 05 \\
\hline SOWCARPET & 18 \\
\hline MYLAPORE & 07 \\
\hline ANNASALAI & 06 \\
\hline PERAMBUR & 04 \\
\hline EGMORE & 03 \\
\hline TOTAL & $\mathbf{7 5}$ \\
\hline
\end{tabular}




\section{Analysis Of Marketing Strategies Adopted By Gold Jewellers In Chennai}

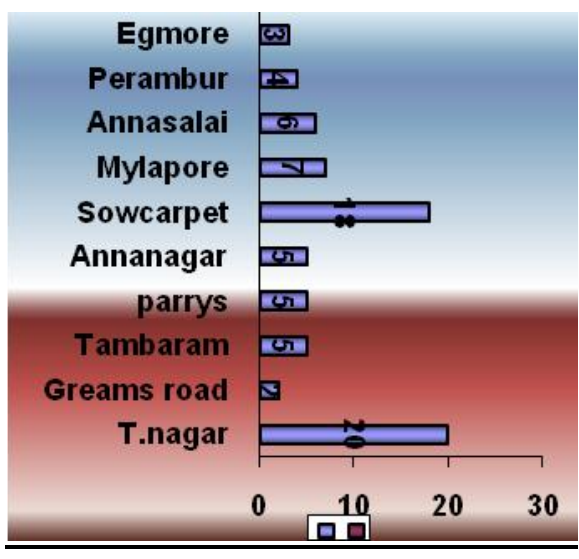

The researcher conducted personal interview in the above areas with the help of structured questionnaire. The questionnaire consists of open and closed ended questions. [13], [15],[17]

Table 1 Types of gold jewels

\begin{tabular}{|l|l|l|}
\hline Factor & Respondents & Percentage \\
\hline $22 \mathrm{karat}$ & 30 & 40 \\
\hline $916 \mathrm{kdm}$ & 45 & 60 \\
\hline Total & 75 & 100 \\
\hline
\end{tabular}

Inference:

* $60 \%$ of the respondents offered $916 \mathrm{kdm}$ gold jewels.

Remaining $40 \%$ of the respondents offered 22 karat gold jewels.

Table - 2 Preference of customer for gold jewels

\begin{tabular}{|l|l|l|}
\hline Factor & Respondents & Percentage \\
\hline 22 karat & 22 & 30 \\
\hline $916 \mathrm{kdm}$ & 53 & 70 \\
\hline Total & 75 & 100 \\
\hline
\end{tabular}

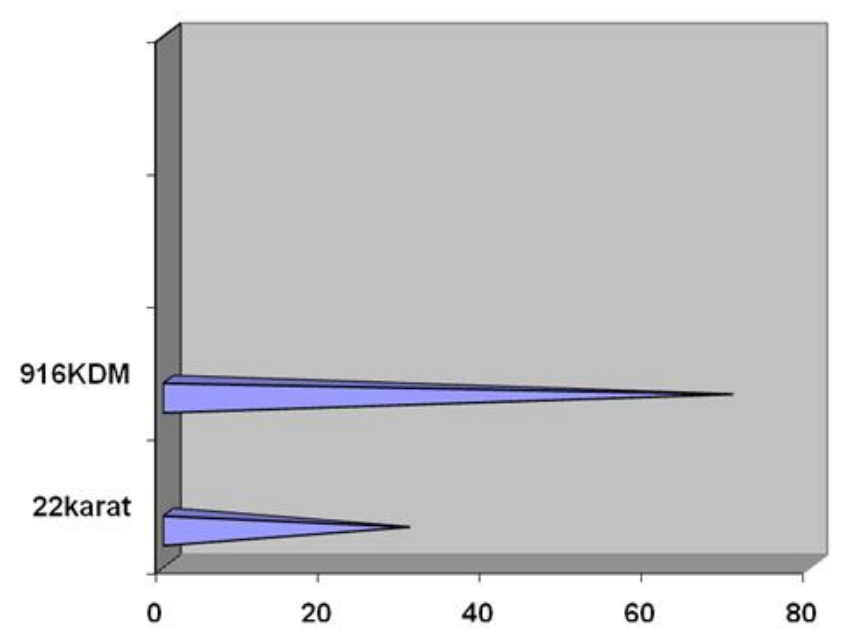

Figure - 1 Preference of customer for gold jewels

\section{Inference:}

$\$ 70 \%$ of the respondents said that the customers preferred $916 \mathrm{kdm}$ gold jewels.

* Remaining $30 \%$ of the respondents said that the customers preferred 22 karat gold jewels
Table 3 Offers provided by jeweler shops

\begin{tabular}{|l|l|l|}
\hline Factor & Respondents & Percentage \\
\hline No wastage & 13 & 17 \\
\hline No Making Charges & 30 & 40 \\
\hline Free Gemstones & 20 & 27 \\
\hline Reduction in basic price & 12 & 16 \\
\hline Total & 75 & 100 \\
\hline
\end{tabular}

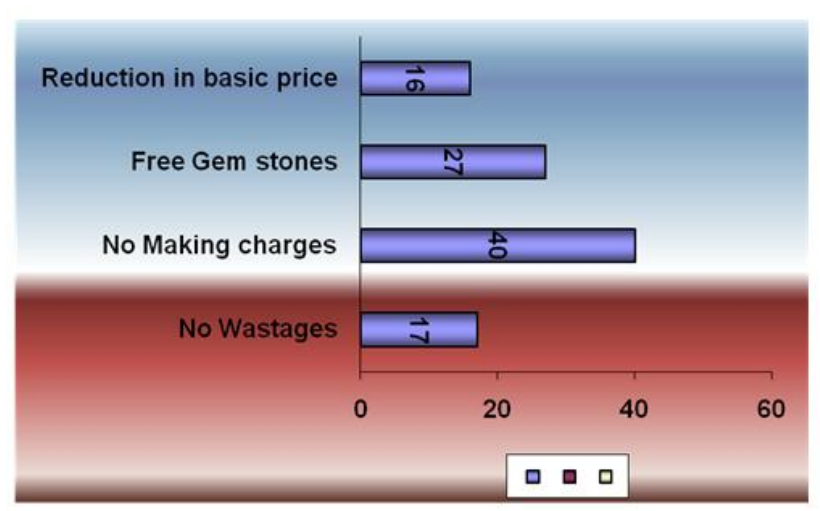

Figure 2 Offers provided by jeweler shops

Inference:

$40 \%$ of the respondents offering No making charges to the customers.

* $27 \%$ of the respondents offering Free gem stones to the customers.

* $17 \%$ of the respondents offering No wastage to the customers.

* Remaining $16 \%$ of the respondents offering Reduction in basic price to the customers.

Table 4 Competitor reduces the basic price

\begin{tabular}{|l|l|l|}
\hline Factor & Respondents & Percentage \\
\hline Giving offers & 25 & 33 \\
\hline Maintain our own strategy & 50 & 67 \\
\hline Total & 75 & 100 \\
\hline
\end{tabular}

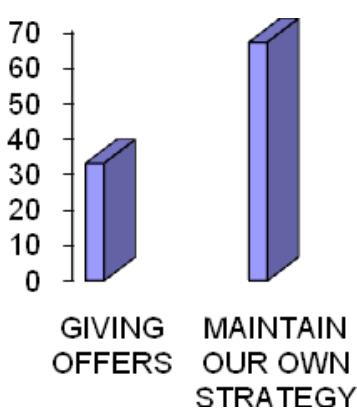

Figure 4 Competitor reduces the basic price

Inference:

* $67 \%$ of the respondents said that we would maintain our own strategy when the competitor reduces the basic price also. 
* Remaining $33 \%$ of the respondents said that we would give offers when the competitor reduces the basic price.

Table 5 Schemes provided by the jeweler shops

\begin{tabular}{|l|l|l|}
\hline Factor & Respondents & Percentage \\
\hline Advance Booking Schemes & 24 & 32 \\
\hline Marriage scheme & 7 & 9 \\
\hline Saving Scheme & 44 & 59 \\
\hline Total & 75 & 100 \\
\hline
\end{tabular}

Inference:

* $32 \%$ of the respondents offer Advance Booking Schemes to the consumers.

* 59\% of the respondents offer saving scheme to the consumers

* Remaining 9\% of the respondents offer Marriage scheme to the consumers.

\section{RESULTS}

1) $60 \%$ of the respondents offered gold jewels in $916 \mathrm{kdm}$ and remaining $40 \%$ of the respondents offered gold jewels in 22 karat.

2) $70 \%$ of the respondents said that the customers mostly prefer $916 \mathrm{kdm}$ gold jewels only. Remaining $30 \%$ of the respondent only prefers 22 -karat jewels.

3) $40 \%$ of the respondents offering no making charges for gold jewels to make customer attractive. $27 \%$ of the respondents offering free gem stones to encourage customer for repeat purchase. The rest $17 \%$ and $16 \%$ of the respondents offering no wastage and reduction in basic price to maintain the reputation of stores name building[14],[16],[18].

4) Only $33 \%$ of the respondents said that we would give offers when the competitor reduces the basic price. Remaining $67 \%$ of the respondents said that we maintain our own strategy because gold is a valuable asset.

5) $59 \%$ of the respondents (includes large and small scale retailers) offering saving scheme to the consumers while $32 \%$ of the respondents (includes small scale retailers) offering Advance booking scheme schemes to the consumers. Remaining some respondents offering Marriage scheme to the consumers.

6) $51 \%$ of the respondents promoting the product through TV/Radio to reach the customer mind easily. $40 \%$ of the respondents promoting the product through Newspapers \&Magizines to create awareness about the jewellery shop. Remaining some respondents promoting the product through hoardings[19],[21],[23].

7) $40 \%$ of the respondent charge $8-10 \%$ wastage for $8 \mathrm{gm}$ gold jewels $32 \%$ of the respondent charge $10-11 \%$ for $8 \mathrm{gm}$ jewels remaining $28 \%$ of the respondent charge $11 \%$ and above wastage for a $8 \mathrm{gm}$ gold jewels.

8) $58 \%$ of the respondent fix the gold rate mostly based on the association, While $38 \%$ of the respondent fix the gold rate based on government rate, Only some respondent fix the gold rate lesser than the government rate.
9) $56 \%$ of the respondent mainly prefers our jewellery shop for Brand Image, remaining $44 \%$ of the respondent mainly prefers our jewellery shop for stores name.

10) $36 \%$ of the respondent mainly promote the jewellery shop to attract the customers, the $33 \%$ and $28 \%$ of the respondent mainly promote the jewellery for encourage the repeat purchase and for increase the sales volume, Only some respondents promote the jewellery shop to block the competitors move[20],[22],[24].

11) $77 \%$ of the respondents said that Achiayathiti is the important festival for us, remaining $23 \%$ of the respondents said that Deepavali is important for us.

12) $52 \%$ of the respondent introduces the new design once in three months while $43 \%$ of the respondents introduce new design once in a month only some respondents will introduce new design in every six months.

13) $80 \%$ of the respondents provide offer and discounts to the customer, Remaining $20 \%$ of the respondents are not providing any offers and discounts to the customer.

14) $72 \%$ of the respondents are paying advance to the suppliers for the bulk purchase; remaining $28 \%$ of the respondents are not paying any advance to the suppliers for the bulk purchase[25],[27],[29].

15) $56 \%$ of the respondents are said that Brand image is highly valued in our jewellery shop. $37 \%$ of the respondents are said that Brand image is Moderately valued in our jewellery shop. Only some respondents said that Low valued in our jewellery shop.

16) $50 \%$ of the respondents are said that Stores name is highly valued in our jewellery shop. $40 \%$ of the respondents are said that Stores Name is Moderately valued in our jewellery shop. Only some respondents said that Stores name is

Low valued in our jewellery shop

17) $47 \%$ of the respondents are said that Varieties is highly valued in our jewellery shop. $40 \%$ of the respondents are said that Varieties is Moderately valued in our jewellery shop. Only some respondents said that Varieties is Low valued in our jewellery shop.

\section{DISCUSSIONS}

$\square$ The jewellery shop's association has to conduct an exhibition atleast once in a year to create the knowledge about the gold jewels.

Today's market is full of competitive so the jewellery shops have to adopt different strategies to hold the customers with them.

$\checkmark$ Small-scale retailer must promote their product through television $\backslash$ radio to reach customer mind easily.

$\square$ All jewellery shops have to reduce the basic price of gold jewels to attract the customers.

$\square$ Most of the respondents mainly concentrated on Achiayathiti festival. So they have to concentrate and give offers in other festivals also[26],[28],[30].

$\square$ Small-scale retailers should introduce new designs frequently based on their customer's preference.

$\square$ All jewellery shops have to give importance to brand name instead of stores name. 


\section{Analysis Of Marketing Strategies Adopted By Gold Jewellers In Chennai}

Jewellery shops should give more importance on varieties to make the customers for repeat purchase.

$\square$ All jewellery shops should offer EMI schemes to attract customers.

\section{V.CONCLUSION}

The study was conducted to analyze the Marketing Strategies adopted in Gold jewelers in Chennai.

From the study it was inferred the majority of the jewellery shops are adopting different types of strategies to satisfy the customers[31],[33]. Some of the jewellery shops are not adopting any type of strategies they are mainly depended on their stores name. So they have to mainly concentrate on formulation of strategies to fulfill the customer requirements.

\section{REFERENCES}

1) BharthVajan R., Ramachandran S.,Psychographic dimensions of training,2016,International Journal of Pharmacy and Technology,V-8,I-4,P-23727-23729

2) Balakrishnan P., Bharthvajan R.,A study on human resource planning in hospitals in Chennai City,2014,International Journal of Applied Engineering Research,V-9,I-22,P-7503-7507

3) Priyadarsini P., Bharthvajan R.,Role of emotional intelligence training programme in reducing the stress of the nurses,2014,International Journal of Applied Engineering Research,V-9,I-22,P-7411-7421

4) Kerinab Beenu G., Bharthvajan R.,Empirical analysis on the cosmetic buying behavior of young women in South India,2014,International Journal of Applied Engineering Research,V-9,I-22,P-7361-7366

5) Balakrishnan P., Bharthvajan R.,Whistling in the wind,2014,International Journal of Applied Engineering Research,V-9,I-22,P-7586-7593

6) Krishnan B., Peter M.,Health hazards of Indian Bpo employee-an alarming issue,2014,International Journal of Applied Engineering Research,V-9,I-22,P-7336-7341

7) Kerinab Beenu G.H., Peter M.,Role of insurance in economic development,2014,International Journal of Applied Engineering Research,V-9,I-22,P-7532-7539

8) Balakrishnan P., Peter M., Priyadarsini P.,Efficiency of safety measures for wellbeing of employees in manufacturing industry,2014,International Journal of Applied Engineering Research,V-9,I-22,P-7376-7382

9) Anbarasi M., Praveen Kumar S.,Online sales promotions of herbal products and its effectiveness towards tanisha.com,2019,Indian Journal of Public Health Research and Development,V-10,I-1,P-195-200

10) Anbarasi M., Praveen Kumar S.,Various online marketing and promotions strategies to improve the validation towards the organic products in the pharmaceutical sectors, 2019,Indian Journal of Public Health Research and Development, V-10,I-1,P-263-269

11) Loganathan R., Praveen Kumar S.,Grievance handling a key factor for solving issues of employees in an organization,2014,International Journal of Applied Engineering Research,V-9,I-22,P-7483-7491

12) Loganathan R., Praveen Kumar S.,Study on preference of private label brands in super and Hypermarkets,2014,International Journal of Applied Engineering Research,V-9,I-22,P-7327-7335

13) Smitha M., Praveen Kumar S.,Understanding stress and its managementamong the nurses in Chennai city,2014,International Journal of Applied Engineering Research,V-9,I-22,P-7560-7565

14) Kerinab Beenu G.H., Praveen Kumar S.,A study on the investment behavior of Chennai investors in mutual fund schemes,2014,International Journal of Applied Engineering Research,V-9,I-22,P-7520-7525

15) Loganathan R., Praveen Kumar S.,Retention strategies key for organizational productivity,2014,International Journal of Applied Engineering Research,V-9,I-22,P-7443-7447

16) Pavithra J., Ganesan M., Brindha G.,State wise analysis of microfinance sector in India,2016,International Journal of Pharmacy and Technology,V-8,I-4,P-23417-23432

17) Pavithra J., Ganesan M.,A comparative study on microfinance in India and abroad,2016,International Journal of Applied Business and Economic Research,V-14,I-8,P-5471-5476
18) Pavithra J., Ganesan M.,A study on awareness and impact of micro-financial schemes,2016,International Journal of Applied Business and Economic Research,V-14,I-8,P-5449-5460

19) Senthilmurugan P., Pavithra J.,Consumer preference towards organised retailing with reference to Big Bazaar,2014,International Journal of Applied Engineering Research,V-9,I-22,P-7469-7475

20) Senthilmurugan P., Pavithra J.,Implication of social media marketing in growing healthcare industry,2014,International Journal of Applied Engineering Research,V-9,I-22,P-7448-7456

21) Loganathan R., Pavithra J.,Consumer perception towards private label brand over other brands in super markets and hypermarkets,2014,International Journal of Applied Engineering Research,V-9,I-22,P-7355-7360

22) Kerinab Beenu G., Pavithra J.,Tradeâ€"off between liquidity and profitability in logistics industry,2014,International Journal of Applied Engineering Research,V-9,I-22,P-7398-7401

23) Kerinab Beenu G., Pavithra J.,A study on the prospective consumerâ€ $\mathrm{TM}_{\mathrm{S}}$ perception towards utility cars in Chennai city,2014,International Journal of Applied Engineering Research,V-9,I-22,P-7526-7531

24) Pavithra J., Dilli Babu P., Ambuli T.V.,A study on budgetary control at Maruti Service Masters, Chennai,2014,International Journal of Applied Business and Economic Research,V-12,I-2,P-151-161

25) Pavithra J., Dilli Babu P., Ambuli T.V.,A study on customer satisfaction of retro Garments Pvt Ltd, Chennai,2014,International Journal of Applied Business and Economic Research,V-12,I-2,P-381-391

26) Kerinab Beenu G.H., Pavithra J., Senthilmurugan P.,A study on the influence of promotional activities for TATA ARIA among consumers in Chennai,2014,International Journal of Applied Engineering Research,V-9,I-22,P-7572-7578

27) Vijayaragavan S.P.,An investigative expert that's general FBG sensors,International Journal of Mechanical Engineering and Technology,V-8,I-8,PP-1500-1505,Y-2017

28) Vijayaragavan S.P.,Equalization routing protocol for Wi-Fi sensor strategy,International Journal of Mechanical Engineering and Technology,V-8,I-8,PP-1662-1666,Y-2017

29) Karthik B., Kiran Kumar T.V.U., Vijayaragavan P., Bharath Kumaran E.,Design of a digital PLL using 0.35 $\hat{\mathrm{I}}^{1} / 4 \mathrm{~m}$ CMOS technology,Middle East Journal of Scientific Research,V-18,I-12,PP-1803-1806,Y-2013

30) Kanniga E., Selvaramarathnam K., Sundararajan M.,Kandigital bike operating system,Middle - East Journal of Scientific Research,V

31) Jasmin M., Vigneshwaran T., Beulah Hemalatha S.,Design of power aware on chip embedded memory based FSM encoding in FPGA,International Journal of Applied Engineering Research,V-10,I-2,PP-4487-4496,Y-2015

32) Jasmin M.,Optimization techniques for low power VLSI circuits,Middle East Journal of Scientific Research,V-20,I-9,PP-1082-1087,Y-2014

33) Jasmin M., Vigneswaran T.,Fuzzy controller for error control of on - Chip communication,2017 International Conference on Algorithms, Methodology, Models and Applications in Emerging Technologies, ICAMMAET 2017,V-2017-January,I-,PP-1-5,Y-2017

\section{AUTHORS PROFILE}

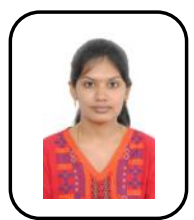

M. Anbarasi Research Scholar, Department of MBA, Bharath Institute of Higher Education and Research, Chennai, India.

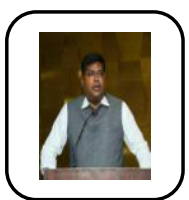

Dr. S. Praveen Kumar Professor, Department of MBA, Bharath Institute of Higher Education and Research, Chennai, India. 